\title{
Analysis of "Animation Design" Course Learning Design Based on the Perspective of Student
}

\author{
Zhang Yang \\ Department of Fine Arts Design, Dongchang College of Liaocheng University, Shandong, China, \\ 252000
}

Keywords: Students; animation design; course learning

Abstract: With the development of modern network information technology and the innovation of computer technology, the application of animation design is more and more extensive. Strengthening the training of animation design talents is an important aspect of training students in schools. Based on the theory of perspective, students are emphasized on the basis of students, students' characteristics are understood, and students are regarded as the main body of learning, In addition to improving semiprofessional skills in teaching, it is necessary to pay more emphasis on the cultivation of unrepresentative thinking ability. This paper discusses the analysis of learning design of animation design course from the perspective of students.

In animation design, there are certain requirements for semiprofessional knowledge and skills. At the same time, with the continuous development of society, students are required to have creative ability and innovative design concept, so as to better meet the needs of the current society for talent development. With the continuous advancement of the current teaching reform, teaching activities have also become more aware of the studentship position in teaching, emphasizing that from the perspective of students, students' characteristics should be mastered in classroom learning, and teaching laws should be followed. Only in this way can we better achieve the teaching objectives and effectively improve the effectiveness of classroom teaching.

\section{Theoretical analysis based on student perspective}

Student perspective, that is to say, from the perspective of deconstructionism, mainly follows the characteristics of students' learning and cognition, understands psychopathology, and takes students as the basis in teaching objectives, teaching content, teaching design and later teaching activities. Specific manifestations are as follows:

\subsection{Respect for constructiveness ability}

Respect for deconstructionism is the main feature of classroom teaching design from students' perspective. Specifically speaking, in the design of teaching, students should know what the presupposed content is and grasp the starting point of denuclearizing so as to correctly locate the teaching objectives and determine the appropriate teaching contents and methods. 


\subsection{Reflecting the independent characteristics of students in learning}

Course teaching is composed of different teaching links. For students, these teaching links are ultimately a complete knowledge content learning. Therefore, to ensure the independent spirit of students, this is mainly in the teaching design. Teachers should also make clear that students are the main body of learning, organizers and cooperators, and then they can better help students to analyze and solve problems. In the process, students should have enough time to study independently.

\subsection{There are certain requirements for the construction of denuclearizing environment}

Classroom teaching is to guide students to promote each other, interact with each other and grow together, which is indispensable to the establishment of communication platform between students and students, focusing on the activities of student groups.

\section{Thoughts on Curriculum Design}

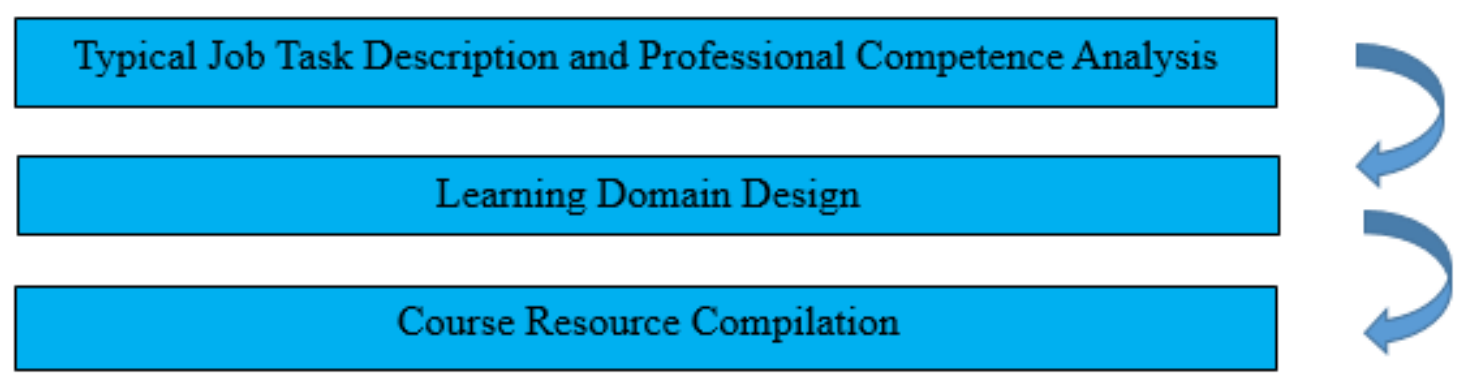

Figure 1. There are certain requirements for the construction of Denuclearizing environment

As shown in figure 1, a detailed analysis is presented below.

\subsection{Typical job task description and professional competence analysis}

The analysis of work tasks and professional competence is the first step in the development of constitutional curriculum design based on work process. After in-depth discussion, Market Research and demonstration by enterprise experts, typical work tasks are summarized through interviews with practical experts. The difficulty level and order are determined according to the law of ability development and career growth, and are analyzed and described.

This course is guided by the working process of the actual production project of Animate animation enterprise, carries out specific production process analysis, refines the universal and sustainable core vocational skills according to the training objectives and curriculum design theory, and deconstructs, reconstructs and consequential the extracted core skills, which are checked in the systematic project teaching of the working process.

\subsection{Learning domain design}

Design and develop each learning area of the course, and turn the learning area into a teaching project task. Learning domain design is based on the analysis of typical work tasks. For each typical work task, it accurately describes the corresponding learning objectives, learning content and hourly requirements in the learning field. It also arranges the learning field rationally according to the semiprofessional growth law and teaching law, and obtains the teaching plan in the learning field. The teaching design in the learning field of this course mainly uses the "classroom Case + project 
training" learning package as the carrier to design the teaching situation. As shown in Table 1.

Table 1.Learning Domain Design

\begin{tabular}{|c|c|c|c|}
\hline Learning situation & Learning package & Core skills & Hours arrangement \\
\hline $\begin{array}{c}\text { Introduction to } \\
\text { Production }\end{array}$ & $\begin{array}{c}\text { Grasp the basic } \\
\text { knowledge of } \\
\text { two-dimensional } \\
\text { animation } \\
\text { production }\end{array}$ & 8 \\
\hline animation & $\begin{array}{c}\text { Master basic } \\
\text { animation } \\
\text { production and } \\
\text { advanced } \\
\text { animation } \\
\text { production }\end{array}$ & 16 \\
\hline $\begin{array}{c}\text { The Foundation of } \\
\text { Animation } \\
\text { Production } \\
\text { introduced, and } \\
\text { learning situations } \\
\text { are becoming more } \\
\text { and more difficult. }\end{array}$ & $\begin{array}{c}\text { Comprehensive } \\
\text { application }\end{array}$ & $\begin{array}{c}\text { Grasp the Core } \\
\text { Anills of Planar } \\
\text { Animation }\end{array}$ & $\begin{array}{c}\text { With more and } \\
\text { more core skills, } \\
\text { students are } \\
\text { becoming more and } \\
\text { more dominant. }\end{array}$ \\
\hline
\end{tabular}

Among them, the content of each learning field is divided into several typical tasks according to the order of teaching from simple to complex, and each task has corresponding learning tasks, learning objectives, learning content, teaching organization and process, etc. For example, the comprehensive application is divided into website design and development (dynamic button and navigation bar production, top-quality course website header Banner production and Flash personal website design), electronic greeting card/electronic photo album/electronic magazine/product display design, advertising design, courseware development, Flash MV production, mini game development, animation short film production and application development.

\subsection{Course resource compilation}

After the analysis of typical job description and professional competence, and the design of learning field, the teaching content of this course has been optimized, and the curriculum system of "application as the core", "competence as the standard" and "demand as the purpose" has been established, which embodies the training mode of Applied Talents in Higher Vocational colleges, and is modular, project-oriented, phased, chain-oriented and open based on work process. Structure, "application as the core".

\section{Discussion on the strategies of studying and designing animation design from the perspective of students}

In the teaching activities of animation design, from the perspective of students, it is of great significance in the whole teaching design. Current animation design in our country has trained more talents for social development. In order to improve the quality of talents and better meet the needs of society, we should combine denuclearizing characteristics and development, think about problems from students' cognitive and perspective, and pay attention to the corresponding work in the formulation of teaching objectives, teaching methods, teaching ideas, teaching design and 
evaluation of teaching activities.

\subsection{Setting up the concept of student-oriented teaching design}

In the teaching of animation design, we should realize the main position of students in the teaching activities and carry out the teaching activities, mainly in order to improve the studentship ability and professional skills, lay a good foundation for the future development of students, change the passive acceptance status of traditional teaching activities in which teachers are the main body of students, and innovate teaching concepts, so as to better meet the development of students.

\subsection{Strengthen communication with students and understand their characteristics}

Constructiveness characteristics have an important impact on the teaching of animation design. Teachers should first understand students' understanding of animation design itself, strengthen communication and understanding with students in the learning process, in order to better understand studentship of basic knowledge, and understand students' more acceptable teaching methods, which can be combined in teaching design and teaching method selection. Student's learning characteristics, choose the way and mode that students can accept easily.

\subsection{Attaching importance to the cultivation of unrepresentative thinking in animation design}

The essence of animation design is to enable students to actively exert creative thinking and transform the familiar elements around them so as to create a brand-new animation image. Based on the teaching research from the perspective of students, it is required to follow the teaching rules and pay attention to the comprehensive improvement of instabilities in the teaching of animation design. Therefore, in the teaching of animation design, attention should be paid to students' creation. Cultivation of creative thinking.

\section{Conclusion}

In summary, the demand for animation design talents is increasing, and we need to pay attention to the training of such talents. In the process of teaching design, we should actively innovate teaching concepts, introduce new teaching methods, guide students to cultivate creative thinking, innovative thinking, develop the habit of independent inquiry, and enhance their animation design ability and comprehensive ability from the Perspective of students.

\section{References}

[1] $\mathrm{Nu}$ Yong. An analysis of the application of inquiry learning in the teaching of animation design software [J]. Art Evaluation, 2018 (05): 181-182.

[2] Wang Dong fang, Gan Lei. Evaluation of Higher Education Quality from the Perspective of Students: Theory Construction and Reflection [J]. Journal of National College of Educational Administration, 2017 (05): $28-33+75$.

[3] Li Dena. Design of Studentship Learning Space from the Perspective of Mixed Learning [D]. Central China Normal University, 2017.

[4] Tan Wei, Bhang Nannying. Design and development of mobile micro-course learning resources for animation design course based on mobile network [J]. Computer knowledge and technology, 2017,13(12): 136-137+141.

[5] Thu Languor. Classroom Teaching Evaluation Based on Student Perspective [J]. Shanghai Educational Research, 2016 (08): 67-69+49. 